\title{
SIKAP PEROKOK AKTIF DALAM MENANGGAPI PERINGATAN BAHAYA MEROKOK PADA IKLAN ROKOK DI TELEVISI \\ (Studi Masyarakat Desa Talang Jambu Kecamatan Kerkap Kabupaten Bengkulu Utara)
}

Oleh:

\author{
META JUWITA SARI, YANTO, SAPTA SARI \\ Program Studi Ilmu Komunikasi Fakultas Ilmu-Ilmu Sosial \\ Universitas Dehasen Bengkulu
}

\begin{abstract}
The attitude of active smokers in smoking bans on cigarette advertisements can communicate their products as commodities that are connected with glamor, energy and lifestyle. The cigarette industry leads children to become beginner smokers through advertisements, promotions that are present in television media. Cigarette companies compete to make advertisements as creative as possible with the aim of increasing sales. Based on the background above the formulation of the research problem is how the attitudes of active smokers in responding to the warning of hazards on cigarette advertisements on television. Based on the research problem above, the aim of the study is to find out the attitudes of active smokers in responding to the warning of hazards on cigarette advertisements on television. The methodology in this study uses qualitative research with data collection technique of observation, interviews and documentation. The results of the study stated that the informants were afraid with the contents of message on public service advertisements (ILM) about the dangers of smoking. This can be seen from the interview quote from the informant's answer. The informant saw ILM about the dangers of smoking being broadcast on television. In this study, almost all of the informants said that first the informants began to try to smoke because there was a feeling of insecurity if they did not smoke while gathering with friends in the neighborhood. There were also informants who smoked because of great curiosity, so the intention was to try to smoke cigarettes. Even the informant who said that one of the factors that made the informant curious and wanted to try cigarettes was because the informant saw the parents of informants who smoked at home. Active smokers try to smoke because there are influences from family factors and the environment where they live. Based on this this research, it is expected that the environment can help active smokers no longer depend on cigarettes.
\end{abstract}

Keywords: Attitude, Cigarette Advertisement, Danger of Smoking

\section{PENDAHULUAN}

Merokok merupakan suatu kegiatan yang sering dilakukan oleh masyarakat Indonesia baik itu dilakukan oleh orang dewasa maupun anak remaja sekalipun. Padahal, peringatan tentang bahaya merokok sudah jelas dan bahkan mudah ditemui di tempat-tempat umum seperti pada reklame jalan dengan besar terpampang menyebutkan bahaya merokok seperti serangan jantung, impoten dan gangguan kehamilan. Berdasarkan data dari Badan Konsumsi Tembakau di dunia yang dilansir oleh www.kompasiana.com bahwa Indonesia menempati posisi ke tiga dengan jumlah perokok terbanyak di bawah Cina dan India. Dengan jumlah 65 juta penduduk sebagai perokok aktif dan 270 Miliar batang rokok dibakar setiap tahun. Kemudian penelitian lain dilakukan 
oleh Institute for Health Metrics and Evaluation (IHME), menempatkan Indonesia dalam posisi ke dua jumlah pria perokok terbesar di dunia dengan $57 \%$ dibawah Timor Leste (www.dataperokokdunia.com).

Fenomena rokok selalu menjadi masalah yang belum ada habisnya. Meskipun WHO sudah mengingatkan bahwa rokok merupakan salah satu pembunuh paling berbahaya di dunia, pada kenyataannya produksi rokok tetap menyebar luas diseluruh dunia dengan konsumen yang terus meningkat (www.bahayamerokok.com). Fakta ditemukannya begitu banyak perokok di Indonesia tentunya sangat mengkhawatirkan. Melihat banyaknya kandungan bahan berbahaya dalam satu batang rokok. Dimana setiap satu batang rokok yang di bakar mengeluarkan banyak zat berbahaya diantaranya, Karbonmonoksida yang menyebabkan terhalangnya penyediaan oksigen ke tubuh. Hal tersebut membuat perokok cepat lelah. Zat ini akan mengendap di paru-paru anda dan berdampak negatif pada kinerja paruparu serta nikotin merupakan komponen yang dapat menimbulkan ketergantungan atau kecanduan.

Melihat dampak yang tidak baik akibat rokok, pemerintah tidak tinggal diam begitu saja. Selain mengeluarkan iklan layanan masyarakat, sebelumnya pemerintah juga sudah mengeluarkan beberapa kebijakan berupa UndangUndang maupun Peraturan Pemerintah yang mengatur tentang rokok atau tembakau. Seperti UU No. 32 Tahun 2010 misalnya, Undang-Undang ini berisi tentang kebijakan publik dilarang merokok di tempat umum, tempat kerja, tempat proses belajar mengajar, tempat pelayanan kesehatan, area kegiatan anak-anak, tempat ibadah dan angkutan umum (UU No. 32 Tahun 2010).

Kebijakan lain dari pemerintah selanjutnya adalah PeraturanPemerintah No. 19 tahun 2003 pasal 8 tentang diharuskannya produsen rokok meletakkan pesan bahaya merokok berupa tulisan "MEROKOK DAPAT MENYEBABKAN KANKER, SERANGAN JANTUNG, IMPOTENSI DAN GANGGUAN KEHAMILAN DAN JANIN" pada salah satu sisi kemasan rokok. Selanjutnya, pada tanggal 24 Juni 2014, PP No. 19 tahun 2003 pasal 8 digantikan dengan peraturan baru yaitu, PP No. 109 tahun 2012 pasal 17, tentang gambar peringatan dicantumkan pada bagian atas kemasan sisi lebar bagian depan dan belakang masing-masing seluas $40 \%$ diawali dengan kata "Peringatan" dengan menggunakan huruf berwarna putih dengan dasar hitam, harus dicetak dengan jelas dan mencolok, baik sebagian atau seluruhnya. Gambar peringatan pada bungkus rokok harus dicetak berwarna. Jenis huruf harus menggunakan huruf Arial Bold dengan ukuran font10 (sepuluh) atau proporsional dengan kemasan, tulisan warna putih di atas latar belakang hitam. Gambar dan tulisan peringatan kesehatan tidak boleh tertutup oleh apapun sesuai dengan ketentuan peraturan perundang-undangan (PP No. 109 tahun 2012 pasal 17).

Data terbaru dari Riskesdas 2013 menyatakan perilaku merokok penduduk 15 tahun keatas masih belum terjadi penurunan dari 2007 ke 2013, cenderung meningkat dari 34,2 persen tahun 2007 menjadi 36,3 persen tahun 2013 (Riskesdas, 2013). Peningkatan jumlah tersebut menjadi salah satu indikator yang merefleksikan peningkatan angka perokok khususnya pada remaja. Data tersebut diperkuat dengan hasil Riskesdas 2013 dimana angka kebiasaan merokok tertinggi di Indonesia adalah tamatan SMA yaitu sebanyak 28,7 persen (Riskesdas, 2013). Peningkatan angka perokok usia remaja ini tentunya mempunyai dampak masalah yang (www.dataperokokdiindonesia.co.id).

Banyaknya jumlah perokok ada pengaruh dari media elektronik seperti televisi. Dengan media elektronik, semua orang bisa mendapat informasi dan berita terkini, baik dari dalam negeri ataupun 
mancanegara. Selain mudah didapat, semua informasi ini juga dapat diakses dengan cepat sehingga menjadikan masyarakat di dunia modern ini menjadi lebih up to date (Saleem dan Anderson, 2012).

Sikap perokok aktif dalam menanggapi peringatan bahaya merokok pada iklan rokok saat ini iklan rokok mampu mengkomunikasikan produknya sebagai komoditi yang identik dengan glamour, energi dan gaya hidup. Industri rokok menggiring anak-anak menjadi perokok pemula melalui iklan, promosi yang hadir dimedia televisi.Perusahanaan rokok berlomba-lomba untuk membuat iklan sekreatif mungkin membuat sebuah iklan dengan tujuan meningkatkan penjualan. Dengan perusahaan membuat sebuah iklan tentunya akan memberikan sikap yang berbeda dari konsumen. Kementrian Kesehatan RI sendiri telah mencanangkan tentang bahaya merokok kepada masyarakat dengan membuat berbagai video-video yang disebarkan keberbagai media, seperti media online, media massa dan media lainnya. Iklan layanan masyarakat berkenaan dengan bahaya merokok dibuat oleh Kementrian kesehatan sangat bervariasi dengan tujuan dapat menginformasikan kepada masyarakat tentang bahaya merokok. Penulis melihat bahwa sedikitnya jam tayang iklan layanan masyarakat yang ada di televisi dibandingkan dengan jam tayang iklan rokok. Contoh peringatan bahaya merokok saat iklan rokok hanya ada tulisan berkenaan bahaya merokok sehingga tidak terlihat dominan saat iklan rokok tayang. Berdasarkan latar belakang tersebut penulis merasa tertarik untuk melakukan penelitian berkenaan dengan Sikap Perokok Aktif Dalam Menanggapi Bahaya Merokok di Desa Talang Jambu Kecamatan Kerkap Kabupaten Bengkulu Utara.

\section{METODE PENELITIAN}

Penelitian ini mengunakan pendekatan kualitatif deskriptif yang menghasilkan prosedur penelitian yang menghasilkan data deskriptif berupa kata-kata tertulis atau lisan dari orang-orang yang berperilaku yang di amati. Metode kualitatif deskriptif adalah metode yang bermaksud membuat penyandaran secara sistematis, faktual, dan akurat mengenai fakta-fakta dan sifat sipat populasi tertentu (Usman dan Akbar, 2004:4) metode ini digunakan untuk mengetahui gambaran sistematis dan kenyataan. Menurut Mulyana dan Solatun(2008:5) penelitian kualitatif adalah penelitian yang bersipat interpretatif (menggunakan penapsiran) yang melibatkan banyak metode dalam masalah penelitian ini lebih cocok digunakan untuk peneliti yang mempetimbangkan kehidupan manusia yang suka berubah ubah.

Dalam menentukan informan, peneliti menggunakan teknik purposive sampling keuntungan dari teknik ini adalah murah, cepat dan relevan dengan tujuan penelitian. Infoman dalam penelitian ini hanyalah sumber yang dapat memberikan informasi yang relevan saja sesuai dengan tujuan penelitian. Dengan kata lain, penelitian siapa yang menjadi sumber data didasarkan atas kriteria tertentu yang sudah di tetapkan terlebih dahulu kriteria yang di maksud adalah perokok aktif. Adapun kriteria pemilihan informan adalah Perokok Aktif dan rentang usia 20 sampai dengan 40 tahun, sering melihat iklan rokok di televisi.

\section{Teknik Pengumpulan Data}

Dalam penelitian ini untuk memperoleh data dari penelitian ini di butuhkan peneliti ialah pengumpulan data melalui wawancara, dokumentasi serta observasi.

\section{Observasi}

Observasi adalah rancangan alamiah untuk menggambarkan realitas sebagai kerangka yang diamati. Pengertian metode observasi definisi menurut para ahli 
dalam penelitian pengertian observasi merupakan teknik pengumpulan data, dimana peneliti melakukan pengamatan secara langsung ke objek penelitian untuk melihat dari dekat kegiatan yang dilakukan (Riduwan, 2004: 104). Saat penelitian penulis akan mengamati sikap perokok aktif.Penelitian ini dilakukan selama kuranglebih satu bulan antara bulan November akhir sampai dengan Desember 2018.

\section{Wawancara}

Pengertian wawancara yang dimaksud dengan wawancara menurut Nazir (1988) adalah proses memperoleh keterangan untuk tujuan penelitian dengan cara tanya jawab sambil bertatap muka antara si penanya atau pewawancara dengan si penjawab atau responden dengan menggunakan alat yang dinamakan interview guide (panduan wawancara). Dalam wawancara memungkinkan pihak yang diwawancarai untuk mendefenisikan dirinya sendiri dan lingkungannya, menggunakan istilah mereka sendiri mengenai sesuatu hal yang berkaitan dengan sikap perokok aktif dalam menanggapi bahaya merokok. Wawancara yang akan dilakukan adalah wawancara terstruktur, artinya wawancara yang pewawancaranya menetapkan sendiri masalah dan pertanyaanpertanyaan yang akan diajukan. Peneliti menggunakan jenis wawancara ini bertujuan mencari jawaban dari rumusan masalah penelitian.

\section{Dokumentasi}

Peneliti mengambil dokumentasi foto-foto kegiatan yang sesuai dengan kebutuhan peneliti. Foto menghasilkan data deskriftif yang cukup berharga dan sering digunakan untuk menelaah segisegi subjektif dan hasilnya sering di analis secara iduktif. Selain menginfetaris foto, peneliti juga mencatat semua kegiatan.

\section{Teknik Analisis Data}

Menurut Sugiyono (2007) teknik analisis data dengan metode penelitian kualitatif mencari dan menyusun secara sistematis dari hasil wawancara, catatan lapangan, dan dokumentasi, dengan cara mengorganisasikan data kedalam kategori, menjabarkan kedalam unit-unit, melakukan sintesa, menyusun kedalam pola, memilih mana yang penting dan yang akan dipelajari, dan membuat kesimpulan sehingga mudah dipahami oleh diri sendiri maupun orang lain.

Dalam penelitian ini menggunakan teknik analisis secara kualitatif. Semua data yang diperoleh dilapangan mengenai pergaulan remaja didalam satu lingkup desa yang memiliki suku dan budaya yang berbeda melalui berbagai sumber yaitu: wawancara mendalam, foto serta studi kepustakaan. Setelah dibaca, dipelajari, dan dikaji maka diklasifikasikan menurut aspek masalah yang ditemukan, kemudian dilanjutkan dengan menganalisa dan menginterpresentasikan data dalam bentuk deskriptif. Hasil analisa dari data yang telah diolah tersebut pada akhirnya ditarik untuk diambil sebuah kesimpulan.

\section{HASIL PENELITIAN DAN PEMBAHASAN}

\section{Kognisi}

Gejala kognisi meliputi, pengamatan aktivitas yang dilakukan seseorang yang cerdas, terhadap suatu proses atau objek dengan maksud merasakan dan kemudian memahami pengetahuan dari sebuah fenomena berdasarkan pengetahuan dan gagasan yang sudah diketahui sebelumnya, untuk mendapatkan informasi-informasi yang dibutuhkan untuk melanjutkan suatu penelitian. Selanjutnya adalah tanggapan yaitu suatu bayangan yang tinggal dalam ingatan setelah kita melakukan 
pengamatan.Tanggapan disini maksudnya ialah tanggapan masa lampau atau tanggapan ingatan, tanggapan masa datang atau tanggapan mengantisipasikan, serta tanggapan masa kini atau tanggapan representative. Selanjutnya ialah ingatan atau proses dari mengingat, menyimpan suatu informasi, mempertahankan dan memanggil kembali informasi tersebut. Kemudian fantasi yang dapat dilukiskan sebagai fungsi yang memungkinkan manusia untuk berorientasi dalamalam imajinasi melampaui dunia riil. Kemudian berpikir yang merupakan proses dinamis yang dapat dilukiskan dengan proses atau jalannya. Terakhir adalah intuisi atau istilah untuk kemampuan memahami sesuatu tanpa melalui penalaran rasional dan intelektualita.

Kebiasaan merokok di Desa Talang Jambu sangat memprihatinkan. Saat penelitian kita dapat menjumpai masyarakat dari berbagai usia. Padahal, berbagai penelitian dan kajian yang telah di lakukan menunjukan bahwa rokok sangat membahayakan kesehatan. Bukan hanya membahayakan para perokok, asap rokok juga sangat berbahaya apabila di hirup oleh orang-orang yang berada di sekitarnya (perokok pasif). Perokok pasif memiliki resiko kesehatan lebih tinggi dari pada para prokok itu sendiri. Penyakitpenyakit mulai dari menderita batuk hingga kanker paru-paru mengancam para perokok aktif maupun pasif. Rokok adalah benda yang mengeluarkan polusi bagi kesehatan paru-paru dan jantung manusia, banyak orang beranggapan bahwa asap rokok yang dihisap akan memberikan kenikmatan tapi disisi lain satu hisapan pada rokok akan mengakibatkan ancaman yang berbahaya bagi kesehatan mereka. Tapi seakan-akan perokok aktif tidak menghiraukan bahaya atau ancaman apa yang akan ditimbulkan dari rokok yang mereka hisap terhadap kesehatan mereka.

Informan yang merokok juga merasa bahwa masalah kesehatan terkait rokok tidak akan menimpa mereka karena mereka masih muda dan kuat. Seperti yang sudah diketahui bahwa didalam satu batang rokok mengandung 4000 jenis senyawa kimia. Dari 4000 jenis senyawa kimia tersebut, terdapat tiga senyawa kimia utama yang dikandung oleh rokok. Tiga senyawa kimia tersebut yaitu, Nikotin, Tar, dan Karbon monoksida.Nikotin adalah zat berbahaya yang menyebabkan kecanduan (adiktif). Tar adalah zat berbahaya yang menyebabkan kanker. Karbon Monoksida (CO), adalah salah satu gas beracun yang menurunkan kandungan oksigen didalam darah. Zat nikotin yang terkandung di dalam satu batang rokok bekerja di otak dengan cara merangsang pelepasan zat dopamine yang memberi rasa nyaman, dan menyebabkan rasa ketergantungan.

Ketika seseorang perokok aktif tidak merokok satu hari saja, maka akan terjadi gejala putus nikotin. Gejala putus nikotin ini diketahui dengan munculnya rasa tidak nyaman, sulit berkonsentrasi, mudah marah, dan lain sebagianya. Sehingga untuk mempertahankan rasa nyaman tersebut, timbul dorongan untuk merokok kembali. Hal inilah yang disebut kecanduan. Unsur rasa takut yang dimaksud di dalam penelitian ini adalah rasa ketakutan yang dirasakan oleh informan terhadap hal mengerikan yang ada didalam pesan iklan rokok di televisi mengenai bahaya merokok. Informan mempunyai jawaban yang hampir sama untuk unsur rasa takut.

Hasil penelitian menyatakan bahwa informan merasa takut terhadap isi pesan yang ada pada Iklan Layanan Masyarakat (ILM) mengenai bahaya merokok. Hal ini dapat dilihat dari kutipan wawancara dari jawaban informan. Informan melihat ILM mengenai bahaya merokok yang disiarkan di televisi. Respon pengendalian ketakutan dapat terjadi jika ancaman yang dirasakan tinggi. Di dalam kondisi seperti ini, seseorang akan percaya bahwa dia rentan terhadap risiko dan percaya bahwa risikonya parah. Hal ini akan menyebabkan rasa takut pada individu. Informan didalam penelitian merasa bahwa 
bahaya merokok yang diangkat sebagai isi pesan seperti memunculkan gambar kanker mulut, memperlihatkan orang dengan kanker tenggorokan, serta cerita hidup mantan perokok aktif yang mengalami kematian merupakan sebuah hal yang menakutkan bagi informan.Pemerintah Republik Indonesia telah menerapkan kebijakan baru terkait penambahan peringatan bergambar pada bungkus rokok pada tanggal 24 Juni 2014.

Kebijakan ini tercantum di dalam Peraturan Pemerintah (PP) Nomor 109 tahun 2012. Didalam Peraturan Pemerintah (PP) ini, produsen rokok di wajibkan untuk menambahkan $40 \%$ gambar seram dalam kemasan rokok yang dijual dimasyarakat. Pada tanggal 10 Oktober 2014, Pemerintah Indonesia mulai meluncurkan ILM bertajuk bahaya merokok yang juga menggunakan gambar seram sebagai isi pesannya. ILM bertajuk bahaya merokok tersebut menggunakan seorang penderita kanker tenggorokan sebagai isi pesan ILM. Adanya visualisasi gambar seram baik dalam bungkus rokok, maupun didalam isi pesan ILM nyatanya cukup efektif dalam menimbulkan ketakutan pada perokok. Penggunaan gambar seram yang terdapat didalam kemasan rokok dapat mengganggu, serta menimbulkan perasaan tertentu pada diri seorang perokok. Negoro (2015) juga menyatakan bahwa, seorang perokok merasakan perasaan tertentu tersebut ketika perokok melihat gambar seram dan cenderung dirasa negatif bagi diri perokok.

Penggunaan gambar seram akan memiliki dampak yang efektif maupun tidak efektif dalam hal penyampaian suatu pesan persuasive salah satu bentuk komunikasi persuasif dengan menakuti seseorang untuk merubah sikapnya. Menakuti dilakukan dengan cara meningkatkan konsekuensi dampak negatif yang akan terjadi pada sasaran pesan persuasif apabila sasaran pesan tidak memenuhi rekomendasi yang sudah dibuat oleh pembuat pesan tersebut.
Pada unsur kerentanan, didapatkan jawaban yang relatif sama informan mengaku bahwa mereka merasakan unsur kerentanan yang dihasilkan oleh isi pesan ILM bertajuk bahaya merokok. Informan tersebut mengaku bahwa setelah mereka melihat isi pesan yang ada di dalam ILM bertajuk bahaya merokok, timbul pemikiran bahwa bisa saja kedepannya nanti mereka juga akan terkena hal-hal berbahaya sama seperti yang ada di dalam isi pesan ILM bertajuk bahaya merokok.

\section{Konasi}

Dalam istilah sehari-hari konasi disebut juga dengan kehendak atau hasrat. Kehendak ialah suatu fungsi jiwa untuk dapat mencapai sesuatu. Kehendak ini merupakan kekuatan dari dalam,dan tampak dari luar sebagai gerak-gerik. Dan hasrat ialah suatu keinginan tertentu yang dapat diulang-ulang. Tenaga-tenaga yang kita gunakan dalam istilah itu sebagai suatu tenaga atau suatu kekuatan yang mendorong kita supaya bergerak dan berbuat sesuatu.

Konasi disebut juga dengan kemauan yang merupakan salah satu fungsi hidup kejiwaan manusia, dapat diartikan sebagai aktivitas psikis yang mengandung usaha aktif dan berhubungan dengan pelaksanaan suatu tujuan. Tujuan adalah titik akhir dari gerakan yang menuju pada suatu arah. Adapun tujuan kemauan adalah pelaksanaan suatu tujuan yang mana harus diartikan dalam suatu hubungan.

Konasi merupakan salah satu fungsi hidup kejiwaan manusia, dapat diartikan sebagai aktivitas psikis yang mengandung usaha aktif dan berhubungan dengan pelaksanaan tujuan. Tujuan adalah titik akhir dari gerakan yang menuju pada suatu arah. Adapun tujuan kemauan adalah pelaksanaan suatu tujuan. Konasi, kehendak, hasrat, kemauan yaitu suatu tenaga, suatu kekuatan yang mendorong kita supaya bergerak dan berbuat sesuatu. Untuk mempermudah mempelajarinya maka gejala kemauan dibagi atas dorongan, keinginan, hasrat, 
kecenderungan dan hawa nafsu. Dorongan dalam dorongan sendiri ada dua golongan yaitu dorongan nafsu serta dorongan rohaniah. Keinginan atau nafsu yang telah mempunyai arah tertentu dan tujuan tertentu. Hasrat, ialah suatu keinginan tertentu yang dapat diulang-ulang. Adapun ciri-ciri Hasrat yang merupakan "motor" penggerak perbuatan dan kelakuan manusia, berhubungan erat dengan tujuan tertentu, baik positif maupun negatif, hasrat tidak dapat dipisah-pisahkan dengan pekerjaan jiwa yang lain. Serta hasrat di arahkan kepada penyelenggaraan suatu tujuan.

Perilaku merokok yang sudah menjadi kebiasaan akan menyebabkan kecaanduan bagi para pengkonsumsi rokok itu sendiri, mereka akan cenderung tidak peduli terhadap bahaya-bahaya bagi dirinya sendri maupun bagi orang lain akibat dari asap rokok yang mereka hisap. Dalam penelitian ini peneliti mengetahui alasan informan merokok. Informan yang merupakan perokok aktif tetap merokok karena beberapak factor diantaranya adalah faktor kepribadian (diri sendiri), keluarga, dan lingkungan sekitar (sosial).Para informan terbukti tidak peduli akan peringatan larangan merokok, padahal sudah sangat jelas tercantum juga mengenai bahaya merokok bagi kesehatan. Dari hasil wawancara menunjukkan bahwa seseorang yang sudah pernah mengkonsumsi rokok akan sulit untuk benar-benar meninggalkan rokok, hal ini Karena merokok membuat seseorang menjadi kecanduan, sekalipun sudah berusaha tapi untuk berhenti merokok namun tetap saja sulit. Kalau niat tersebut belum benar-benar tulus dari hati dan benar-benar belum berniat untuk meninngalkan rokok, kejadiannya akan seperti yang dikemukakan oleh informan penelitian, akhirny kembali lagi pada rokok. Adapun alasan lain perokok sulit untuk berhenti merokok dikarenakan adanya efek candu yang diberikan oleh rokok itu sendiri.
Informan di dalam penelitian ini hampir semua mengatakan bahwa pada mulanya informan mulai mencoba untuk merokok adalah karena adanya rasa tidak percaya diri jika tidak merokok saat berkumpul dengan teman lingkungan tempat tinggal. Ada juga informan merokok adalah karena rasa penasaran yang besar sehingga muncul niat untuk mencoba menghisap rokok. Bahkan juga informan yang mengatakan bahwa salah satu faktor yang membuat informan penasaran dan ingin mencoba rokok adalah karena informan melihat orang tua informan yang merokok di rumah. Kegiatan menirukan perilaku orang lain merupakan salah satu faktor dalam memulai perilaku merokok. BlancoEt al.,(2012) dan Rafiee dkk (2010) di dalam hasil penelitiannya ditemukan bahwa memiliki rekan perokok, atau orang tua yang perokok merupakan faktor yang paling penting sebagai pendorong untuk menjadi seorang perokok juga. Terdapat hubungan antara kegiatan merokok, dengan memiliki teman perokok.Awal perokok cenderung melihat orang tua yang merokok, baik bapak, ibu maupun keluarga yang lain. Berawal dari masa remaja yang melihat orang tua merokok akan menyebabkan timbulnya rasa pada diri remaja untuk mencoba apa yang dilakukan orang tua mereka. Keakraban serta seringnya waktu para berkumpul, dan seringnya berkomunikasi akan membuat seseorang yang merokok sangat mudah mempengaruhi teman yang tidak merokok menjadi seorang perokok.

Informan dalam penelitian ini juga memiliki alasan yang beragam tentang kebiasaan merokok yang hingga saat ini masih mereka lakukan. Berdasarkan hasil penelitian didapatkan informasi bahwa informan mengakui masih merokok hingga saat ini karena sudah merasa ketergantungan, atau sudah merasa kecanduan. Sedangkan informan lain memiliki alasan yang berbeda-beda. Seorang informan mengatakan bahwa dirinya masih merokok karena belum 
menemukan alasan yang cocok untuk berhenti merokok. seorang informan lainnya beralasan masih merokok hingga saat ini karena membutuhkan rokok untuk menjaga tubuhnya agar tetap bisa terjaga, sehingga bisa mengerjakan pekerjaan sehari-hari dengan lebih konsentrasi. Seorang lainnya beralasan masih merokok hingga saat ini karena faktor lingkungan di sekitarnya. Informan merasa sulit berhenti merokok karena sudah merasakan efek ketergantungan, dan kecanduan rokok.

\section{Afeksi}

Menurut Schutz (1980) dalam Sarwono (1991:164) kebutuhan afeksi (kasih sayang) merupakan kebutuhan untuk mengembangkan emosional dengan orang lain. Prinsip dasar afeksi adalah perasaan untuk disukai atau dicintai. Menurut Cronbach dalam Dirgagunarsa (1989:96) kebutuhan afeksi merupakan kebutuhan dimana seseorang ingin memperoleh respon atau perlakuan hangat dari orang lain, misalnya orang tua, guru atau teman-teman. Sedangkan Maslow (Goble, 1987:74), kebutuhan akan cinta atau kasih sayang yaitu kebutuhan untuk dimengerti secara mendalam, dan didalamnya ada unsur memberi dan menerima. Menurut Maslow apabila kebutuhan akan rasa aman telah terpenuhi, maka muncullah kebutuhan akan cinta, kasih sayang dan rasa memiliki-dimiliki. Maslow (Goble, 1987:75) menyebutkan bahwa tanpa cinta dan kasih sayang maka pertumbuhan dan perkembangan kemampuan orang akan terhambat. Terhalangnya pemuasan kebutuhan akan cinta dan kasih sayang merupakan penyebab dari salah penyesuaian. Sedangkan menurut Fromm (2005:33) karakter aktif dari cinta adalah perhatian, rasa hormat, tanggung jawab dan pemahaman.Berdasarkan penjelasan diatas maka penulis melakukan wawancara berkenaan dengan sikap yang diharapkan dari lingkungan tempat penelitian.

Berdasarkan hasil peneltian yang dilakukan dapat penulis pahami bahwa sikap yang diharapkan oleh perokok aktif dalam membantu perokok aktif agar tidak merokok lagi.Perokok aktif mencoba merokok karena adanya pengaruh dari factor keluarga, lingkungan tampat tinggal tentunya perokok aktif dalam hal ini sebagai informan penelitian mengharapkan lingkungan dapat membantu agar tidak ketergantungan dengan rokok. Namun kebalikan dari apa yang diharapkan oleh informan lingkungan tempat tinggal memberikan respon saat ada anggota keluarga yang baru mulai merokok sehingga perokok aktif merasa tidak ada ancaman dan dapat merokok dengan nyaman.

\section{PENUTUP \\ Kesimpulan}

Berdasarkan hasil penelitian dan pembahasan diatas maka dapat penulis simpulkan bahwa sikap perokok aktif dalam menanggapi peringatan bahaya merokok pada iklan rokok di televisi sebagai berikut:

\section{Kognisi}

Hasil penelitian menyatakan bahwa informan merasa takut terhadap isi pesan yang ada pada Iklan Layanan Masyarakat (ILM) mengenai bahaya merokok. Hal ini dapat dilihat dari kutipan wawancara dari jawaban informan. informan melihat ILM mengenai bahaya merokok yang disiarkan di televisi.

\section{Konasi}

Informan di dalam penelitian ini hampir semua mengatakan bahwa pada mulanya informan mulai mencoba untuk merokok adalah karena adanya rasa tidak percaya diri jika tidak merokok saat berkumpul dengan teman lingkungan tempat tinggal. Ada juga informan merokok adalah karena rasa penasaran yang besar sehingga muncul niat untuk mencoba menghisap rokok. Bahkan juga informan yang 
mengatakan bahwa salah satu faktor yang membuat informan penasaran dan ingin mencoba rokok adalah karena informan melihat orang tua informan yang merokok di rumah.

\section{Afeksi}

Perokok aktif mencoba merokok karena adanya pengaruh dari faktor keluarga, lingkungan tampat tinggal tentunya perokok aktif dalam hal ini sebagai informan penelitian mengharapkan lingkungan dapat membantu agar tidak ketergantungan dengan rokok.

\section{Saran}

1. Sebaiknya orangtua yang merokok agar tidak merokok di tempat umum atau didepan anak, dan tempat umum.

2. Pemerintah memberikan tindakan tegas apabila ada yang merokok. Selain itu pemerintah dapat menaikkan harga rokok sehingga rokok hanya dapat dibeli beberapa konsumen saja.

\section{DAFTAR PUSTAKA}

Agung. 2000. Metodelogi Penelitian Kualitatif. Jakarta, Karya Fana

Badudu Js, Kamus Besar Bahasa Indonesia. 1998. Jakarta, Pustaka Sinar Harapan.

Djam'ah. 2009. Metode Penelitian Kualitatif Pemula. Bandung, PT Remaja Rosdakarya.

Hanurawan. 2007. Psikologi Komunikasi.Bandung, PT Remaja Rosdakarya.

Luis F. Diaz, M. De Bertoldi, WBidlingmaier. Compost Science and technology. Amsterdam:Elsevi er.
Mulyana, Deddy. 2005. Ilmu Komunikasi Suatu Pengantar. Bandung, PT. Remaja Rosdakarya,

Rakhmat. 2004. Psikologi Komunikasi. Jakarta, PT Bumi Aksara.

Rakhmat, Jalaluddin.2005.Psikologi Komunikasi. Bandung, PT.Remaja Rosdakarya,

Sobur, Alex. 2003. Psikologi uтиm. Bandung, Pustaka Setia,

Sunarwinadi, Ilya. 1993. Komunikasi Antar Budaya.,Jakarta, UI Pers

Sugiyono. 2008. Metode Penelitian Kuantitatif, Kualitatif dan $R \& D$. Bandung,Alfabeta.

Suwandi. 2008. Penelitian Kualitatif. PT Raja Grafindo Persada.

Sugiyono. 2009. Metode Penelitian Kualitatif dan $R \& D C v$, Bandung, Alpabeta.

Sugiyono. 2005.Penelitian Kualitatuf Perspektif Partisipan dengan strategi yang bersifat interaktif dan fleksibel, Cv. Jakarta, Alpabeta

Sugiyono. 2009. Metode Penelitian Pendidikan (Pendekatan Kuantitatif, kualitatif, dan $R \& D)$. Bandung, Alfabeta.

Suharsimi Arikunto. 2003. Manajemen Penelitian. Jakarta, Rineka Cipta.

Prasetyo Dwi, 2013. Pengantar Psikologi. Jakarta, Graha Ilmu

Walgito. 2002. Psikologi Komunikasi. Bandung, Alfabeta. 